\title{
INFLUENCE OF GRAZING ON PLANT DIVERSITY- PRODUCTIVITY RELATIONSHIP IN SEMI-ARID GRASSLAND OF SOUTH AFRICA
}

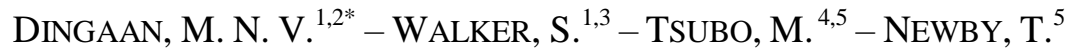 \\ ${ }^{I}$ Department of Soil, Crop and Climate Sciences, University of the Free State, Bloemfontein, \\ South Africa \\ ${ }^{2}$ Department of Life and Consumer Sciences, University of South Africa, Florida, South Africa \\ ${ }^{3}$ Crops For the Future Research Centre, The University of Nottingham Malaysia Campus, \\ Semenyih, Malaysia \\ ${ }^{4}$ Arid Land Research Center, Tottori University, Tottori, Japan \\ ${ }^{5}$ Institute for Soil, Climate and Water, Agricultural Research Council, Pretoria, South Africa \\ *Corresponding author \\ e-mail:dingam@unisa.ac.za \\ (Received $31^{\text {st }}$ Oct 2015; accepted $30^{\text {th }}$ May 2016)
}

\begin{abstract}
The relationship between plant diversity and productivity has been hotly debated over the last two decades. What makes the relationship complex is, in part, the interplay of several biotic and abiotic effects, which include rainfall variability, soil characteristics and grazing. We investigated the influence of grazing intensity on the diversity-productivity relationship in a wide range of soil $\mathrm{pH}$ along a rainfall gradient in semi-arid grassland. Vegetation and soil surveys were conducted in high grazing (HG) and low grazing (LG) grasslands around Bethlehem (716 mm mean annual rainfall, moderately acidic soil), Bloemfontein (543 mm, slightly acidic/neutral soil) and Kimberley $(467 \mathrm{~mm}$, neutral/slightly alkaline soil) in South Africa. Plant species occurring in the study area were recorded, and aboveground biomass was estimated by clippings. Soils sampled were analysed for chemical properties. Species richness increased with increasing biomass and decreasing $\mathrm{pH}$ in Kimberley and Bloemfontein and subsequently declined with increasing biomass and decreasing $\mathrm{pH}$ in Bethlehem. The relationship between species richness and biomass was hump-shaped across the study area but when we differentiated between the degrees of grazing, we found linear positive relationships at both LG and HG sites. This suggests that the diversity-productivity relationship needs to be carefully examined in grazing land.
\end{abstract}

Keywords: biodiversity; biomass; geographical gradient; species richness; soil pH

\section{Introduction}

The relationship between biodiversity and habitat productivity is a hotly debated issue among ecologists and there is no consensus on the nature of the relationship. There is prevailing contention on whether biodiversity depends on productivity or productivity depends on biodiversity (Tilman, 1999), but most importantly, the burning question revolves around the form of the relationship across different ecosystems (Bai et al., 2007; Waide et al., 1999). In natural mature ecosystems, the dominant and classic view is that the productivity-biodiversity relationship most frequently assumes a hump-shaped (unimodal) form in terrestrial ecosystems (Michalet et al., 2006; Mittelbach et al., 2001), while some studies also report a linear positive relationship (Bai et al., 2007; Gillman and Wright, 2006). In experimental assemblages where species richness is controlled, a positive linear relationship is often reported (Hector et al., 1999; Tilman et al., 2001); others attest species 
richness has no significant or consistent effect on productivity (Huston et al., 2000). This suggests that the productivity-biodiversity relationship is complex and there is no single general pattern, but rather the form of relationship varies with the spatial and temporal scales of observation (Waide et al., 1999; Willig, 2011).

The relationship is determined by several biotic and abiotic effects at interplay, including soil characteristics, climate and grazing. Climatic conditions, specifically precipitation, influence plant diversity and productivity (Knapp et al., 2006; Adler and Levine, 2007), as well as soil conditions such as decomposable organic matter and $\mathrm{pH}$ (Troeh and Thompson, 1993). Chemical and physical soil properties influence biomass production, species richness and species composition (Critchley et al., 2002). Most importantly, productivity is strongly affected by the rates at which limiting nutrients such as nitrogen $(\mathrm{N})$, phosphorus $(\mathrm{P})$, and potassium (K) are supplied (Hejcman et al., 2010), while species richness is known to decline with increasing soil nutrient availability (Hejcman et al., 2010; Janssens et al., 1998). In effect, increasing nutrient availability in grasslands favours a few competitive species which have the capacity to rapidly capture resources and accumulate biomass (Critchley et al., 2002). The increased productivity promotes intense competition for light, making it possible for only a few tall, fast growing grasses to replace the slower growing herbs or shrubs (Roem and Berendse, 2000). In arid and semi-arid environments, however, productivity is for the most part limited by precipitation and plant available moisture rather than plant available nutrients (Sullivan and Rohde, 2002).

Grazing also plays an important role in regulating the structure and function of grassland ecosystems (Anderson et al., 2006). Animal trampling may have a major impact on soil structure and subsequently alter the soil water infiltration and availability to plants (Yates, 2000). Grazing is further associated with changes in soil $\mathrm{pH}$ and organic carbon, and soil nutrients such as N, P and K (Cui et al., 2005; Jeddi and Chaieb, 2010; Tefera et al., 2010; Yates, 2010). Accordingly, species composition and biomass production may be influenced through the direct effects of defoliation and trampling, and the indirect effects of nutrient enrichment and depletion (Snyman, 1998; Fernandez-Gimenez and Allen-Diaz, 2001). There is, however, discord in the literature as to the effect of livestock grazing on species richness and productivity. Low grazing pressure has been reported to increase species richness (Oba et al., 2001) while reduced diversity has also been reported with little or no grazing pressure (Anderson et al., 2007). Other studies have failed to detect any grazing effects (Stohlgren et al., 1999). The general view is that species richness may increase or decrease depending on grazing intensity and the amount of biomass (Oba et al., 2001). At low and high grazing pressure, plant richness is low, at intermediate pressure there is maximum species diversity (Oba et al., 2001). Slight or moderate grazing intensity is therefore generally beneficial to maintain biodiversity and aboveground biomass production of grassland ecosystems as compared with grazing exclusion (Milchunas and Lauenroth, 1993). This hump-shaped model is however still an ongoing debate and has, for example, been refuted in a recent review by Fox (2013).

Understanding the interactions among resources availability, species richness and productivity is fundamental to the management and preservation of biodiversity (Mittelbach et al., 2001). Our study is therefore an attempt at gaining better insight into the interactions between productivity, biodiversity and livestock grazing in semi-arid grasslands. We focused on the following question: How does grazing (intensity) affect the productivitybiodiversity relationship in a wide range of soil chemical properties along the rainfall gradient? We use aboveground biomass and species richness as proxies for productivity and biodiversity, respectively. 


\section{Materials and Methods}

\section{Study area}

The study was carried out on Themeda triandra dominated semi-arid grassland around Bethlehem and Bloemfontein in the Free State Province of South Africa, including parts of Kimberley which is situated on the eastern part of the Northern Cape Province (Fig. 1). The vegetation is categorised as climatic climax grassland, a highly productive grassland dominated by sweet grasses (Tainton, 1999), i.e. grasses with high nutritional value that remain palatable throughout the year (Van Oudtshoorn, 1999). According to long-term (1961-2011) rainfall data collected at the three study locations by the Agricultural Research Council-Institute for Soil, Climate and Water and the South African Weather Service, there is a west-east gradient of increasing mean annual rainfall from Kimberley, to Bloemfontein and then Bethlehem. The mean annual rainfall and the standard deviation is $716 \pm 164 \mathrm{~mm}$ in Bethlehem, $543 \pm 165 \mathrm{~mm}$ in Bloemfontein and $467 \pm 145 \mathrm{~mm}$ in Kimberley, of which $82 \%, 79 \%$ and $80 \%$ are summer (October-March) rainfall, respectively. The aridity index (Middleton and Thomas 1992) is lower in Bloemfontein (0.29 for the period of 2004-2010) and Kimberley (0.28) than Bethlehem (0.46). The FAO soil classification shows the soil types across the province to be Luvisol and Lixisol found mainly in the central part of the province, Vertisol in the northeast, Plinthosol in the east, Arensol in the northwest, and Cambisol in the west (FAO/IIASA/ISRIC/ISSCAS/JRC, 2009).

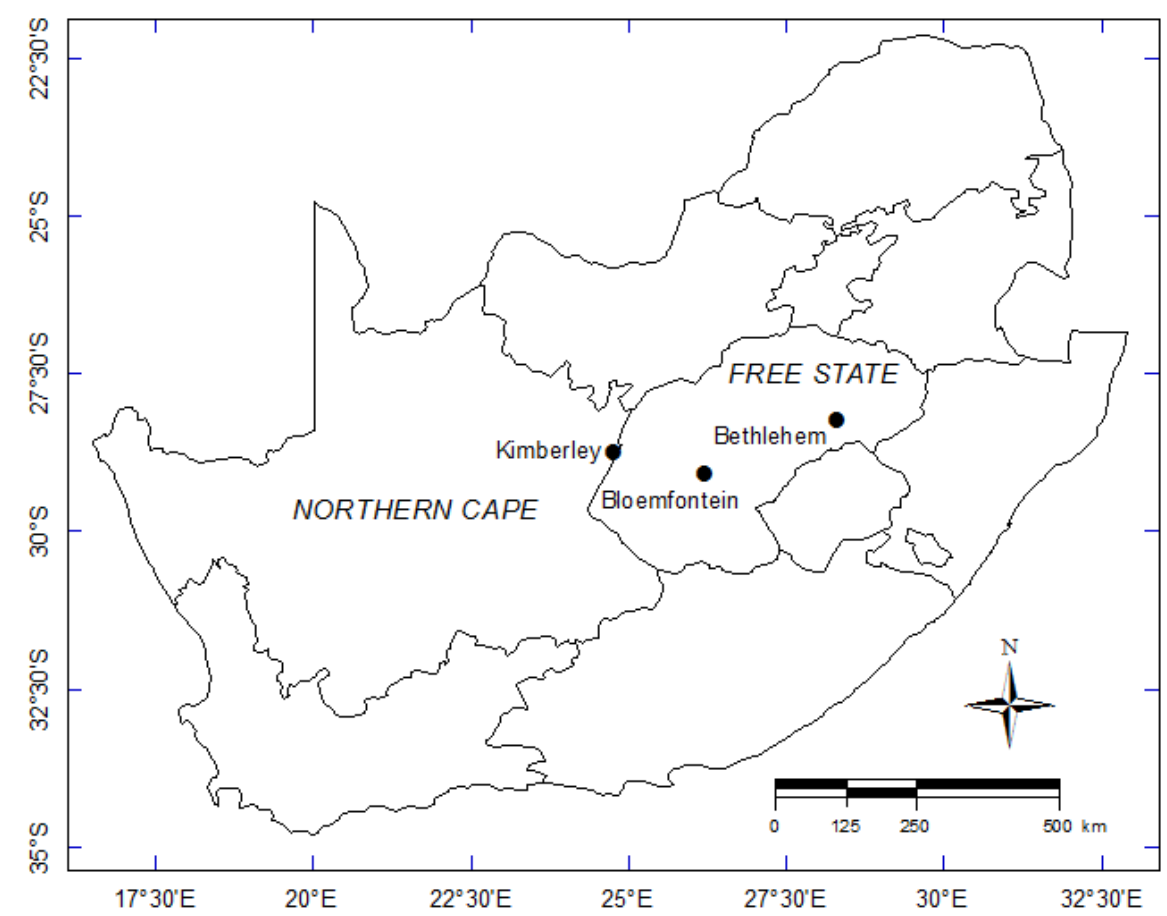

Figure 1. The location of Bethlehem and Bloemfontein in the Free State Province, and Kimberley in the Northern Cape Province, South Africa.

\section{Data collection}

Vegetation surveys were conducted in December 2010 and 2011, in grasslands with differing degrees of utilisation by livestock. We surveyed grassland in private farms, 
communal lands, and also vast open grassland on Municipality land. At each sampling location, we selected roughly $1 \mathrm{~km}^{2}$ portions of grassland, each of which shall be referred to as a site henceforth. The selection of sites was largely dictated by the availability of natural grassland since large areas of grassland in the Free State are utilised for crop farming. We distinguished survey sites into two categories: areas characterised by high grazing $(\mathrm{HG})$ in communal/private farm lands where overgrazing was evident, and low grazing/ungrazed (LG) areas in private farm/protected lands. The communal and private farm lands in Bethlehem were grazed by cattle, and those in Bloemfontein and Kimberley by cattle and/or sheep. LG sites in Bethlehem and Bloemfontein included grazed sites with 0.015 and 0.08 heads $\mathrm{ha}^{-1}$ of cattle grazing intensity, respectively. Grazing intensity in HG sites was not quantified, but the grassland condition of $\mathrm{HG}$ sites where the vegetation survey was conducted was clearly different from that of LG sites. Indicators of HG used were considerable amount of defoliation and trampling, increased area of bare soil, and soil disturbance.

\section{Vegetation and biomass sampling}

Five sites were surveyed in each of the three study locations. At each site, we sampled 2 to 5 plots ( $4 \mathrm{~m}$ by $4 \mathrm{~m}$ in size), depending on the condition of the vegetation. We sampled a total of 70 plots as follows: 11 and 8 plots in LG and HG sites, respectively, in Bethlehem; 23 in LG and 10 in HG in Bloemfontein; 7 in LG and 11 in HG in Kimberley. In each plot, all vascular plant species present were recorded. Species that were problematic to identify in the field were identified at the Geo Potts Herbarium (BLFU) of the University of the Free State. Aboveground biomass was estimated by near-ground clippings of 0.25 to $1 \mathrm{~m}^{2}$ patches in 41 of the 70 sample plots; we excluded plots which were severely overgrazed or where permission was not granted to harvest biomass in private farm land. The clippings were oven dried at $70^{\circ} \mathrm{C}$ for 72 hours.

\section{Soil sampling and analysis}

Three soil samples were taken from 0 to $10 \mathrm{~cm}$ depth in each plot, except at sites surveyed in both 2010 and 2011, where samples were only taken in 2010 (making a total of 44 sample plots). This is mainly because the sample plots suveyed in 2011 were in very close proximity to those in 2010; we therefore worked on the assumption that the soil characeristics were not different. The samples were analysed for chemical properties, i.e. cations $\left(\mathrm{Ca}^{2+}, \mathrm{K}^{+}, \mathrm{Mg}^{2+}\right.$ and $\left.\mathrm{Na}^{+}\right), \mathrm{P}($ Olsen $)$, total $\mathrm{N}$, total carbon $(\mathrm{C})$, and $\mathrm{pH}\left(\mathrm{H}_{2} \mathrm{O}\right)$. All analyses were done according to the methods compiled by the Non-Affiliated Soil Analysis Work Committee (1990), except for total $\mathrm{N}$ and total $\mathrm{C}$ which were analysed with a Carbon/Nitrogen Determinator (LECO Corporation, St. Joseph, MI, USA).

\section{Statistical analysis}

We carried out a nested ANOVA to test the effects of rainfall and grazing on soil chemical properties, aboveground biomass and species richness. The three study locations (i.e. Bethlehem, Bloemfontein and Kimberley) were treated as three levels of rainfall. Grazing with two levels (i.e. LG and HG) was nested within locations. When significant difference was detected, a post-hoc test was conducted: $t$-test for the grazing effect at each location and Tukey's HSD for the rainfall effect. We used regression analysis to examine the relationship between species richness and aboveground biomass across all three locations, thereafter distinguishing between each grazing pressure (LG and HG). The 
relationship for LG was compared with that for HG by using $t$-test. Cook's distance (D) analysis, which detects outliers, indicates that all the data points did not exceed the threshold (i.e. D < 1). All statistical analyses were conducted using SPSS® software.

\section{Results}

\section{Soil chemical properties}

The nested ANOVA results show the effect of rainfall on total $\mathrm{N}$ (Table 1). Bethlehem $(0.16 \pm 0.04 \%)$ had significantly higher $\mathrm{N}$ than Bloemfontein $(0.11 \pm 0.04 \%)$ and Kimberley $(0.08 \pm 0.03 \%)$. In contrast, there was a significant decline in soil $\mathrm{pH}(7.4 \pm 0.5$ in Kimberley, $6.6 \pm 0.8$ in Bloemfontein, and $5.8 \pm 0.3$ in Bethlehem). The results further show the effect of grazing on $\mathrm{Ca}, \mathrm{Mg}$, total $\mathrm{C}$ and $\mathrm{pH}$. A comparison of the soil variables between LG and HG sites revealed $\mathrm{Ca}(p=0.007)$, total $\mathrm{C}(p=0.024)$ and $\mathrm{pH}(p=0.015)$ to be higher at LG than HG sites in Bethlehem; Bloemfontein HG sites had higher $\mathrm{Ca}(p=$ $0.005), \mathrm{Mg}(p=0.011)$ and $\mathrm{pH}(p=0.046)$ than its LG sites; and in Kimberley none of the soil variables was significantly different between LG and HG sites (Table 2).

Table 1. Results of the nested ANOVA for the effects of location and grazing on soil chemical properties, aboveground biomass and species richness

\begin{tabular}{cccc}
\hline Variable & Source & $\boldsymbol{F}$ & $\boldsymbol{p}$ \\
\hline $\mathrm{Ca}$ & Location & 2.358 & $\mathrm{~ns}$ \\
$\mathrm{~K}$ & Grazing (Location) & 4.769 & $* *$ \\
$\mathrm{Mg}$ & Location & 7.305 & $\mathrm{~ns}$ \\
$\mathrm{Na}$ & Grazing (Location) & 0.436 & $\mathrm{~ns}$ \\
$\mathrm{Na}$ & Location & 3.188 & $\mathrm{~ns}$ \\
$\mathrm{P}$ & Grazing (Location) & 4.636 & $* *$ \\
$\mathrm{~N}$ & Location & 1.011 & $\mathrm{~ns}$ \\
& Grazing (Location) & 1.729 & $\mathrm{~ns}$ \\
$\mathrm{C}$ & Location & 0.704 & $\mathrm{~ns}$ \\
& Grazing (Location) & 1.789 & $\mathrm{~ns}$ \\
$\mathrm{NH}$ & Location & 11.752 & $*$ \\
& Grazing (Location) & 1.210 & $\mathrm{~ns}$ \\
Aboveground biomass & Location & 5.423 & $\mathrm{~ns}$ \\
& Grazing (Location) & 3.994 & $*$ \\
Total species richness & Location & 9.909 & $*$ \\
& Grazing (Location) & 3.179 & $*$ \\
Grass species richness & Location & 2.515 & $\mathrm{~ns}$ \\
& Grazing (Location) & 9.759 & $* *$ \\
Forb species richness & Location & 1.099 & $\mathrm{~ns}$ \\
& Grazing (Location) & 15.310 & $* *$ \\
\hline
\end{tabular}

Grazing (Location) refers to grazing effect nested within locations.

Soil properties df $=2$ for Location, 3 for Grazing (Location), 38 for Error

Biomass $\mathrm{df}=2$ for Location, 3 for Grazing (Location), 35 for Error

Species richness $\mathrm{df}=2$ for Location, 3 for Grazing (Location), 64 for Error

$*$, ** and $* * *$ indicate significant at $p<0.05,0.01$ and 0.001 , respectively; ns denotes not significant. 
Table 2. Comparisons of soil chemical properties between low and high grazing sites (LG and $H G$, respectively) in semi-arid grasslands of South Africa. The values are means \pm standard deviations

\begin{tabular}{|c|c|c|c|c|c|c|}
\hline & \multicolumn{2}{|c|}{ Kimberley } & \multicolumn{2}{|c|}{ Bloemfontein } & \multicolumn{2}{|c|}{ Bethlehem } \\
\hline & LG & HG & LG & HG & LG & HG \\
\hline $\mathrm{n}$ & 5 & 8 & 12 & 5 & 8 & 6 \\
\hline $\mathrm{Ca}\left(\mathrm{mg} \mathrm{kg}^{-1}\right)$ & $1937 \pm 1146$ & $2797 \pm 1282$ & $1017 \pm 300$ & $2509 \pm 1549$ & $945 \pm 198$ & $657 \pm 98$ \\
\hline $\mathrm{K}\left(\mathrm{mg} \mathrm{kg}^{-1}\right)$ & $226 \pm 70$ & $275 \pm 155$ & $290 \pm 118$ & $344 \pm 138$ & $206 \pm 119$ & $204 \pm 37$ \\
\hline $\operatorname{Mg}\left(\mathrm{mg} \mathrm{kg}^{-1}\right)$ & $487 \pm 293$ & $308 \pm 90$ & $363 \pm 121$ & $583 \pm 190$ & $202 \pm 64$ & $186 \pm 35$ \\
\hline $\mathrm{Na}\left(\mathrm{mg} \mathrm{kg}^{-1}\right)$ & $48 \pm 24$ & $32 \pm 26$ & $27 \pm 15$ & $34 \pm 28$ & $57 \pm 28$ & $35 \pm 15$ \\
\hline $\mathrm{P}(\mathrm{mg} \mathrm{kg}-1)$ & $5.2 \pm 4.1$ & $2.4 \pm 0.6$ & $3.3 \pm 2.9$ & $5.2 \pm 5.2$ & $2.9 \pm 0.7$ & $2.4 \pm 0.4$ \\
\hline $\mathrm{N}(\%)$ & $0.06 \pm 0.01$ & $0.09 \pm 0.03$ & $0.10 \pm 0.04$ & $0.13 \pm 0.03$ & $0.16 \pm 0.05$ & $0.15 \pm 0.04$ \\
\hline $\mathrm{C}(\%)$ & $0.53 \pm 0.27$ & $0.67 \pm 0.22$ & $0.69 \pm 0.33$ & $0.81 \pm 0.15$ & $1.67 \pm 0.48$ & $1.09 \pm 0.32$ \\
\hline $\mathrm{pH}$ & $7.3 \pm 0.5$ & $7.4 \pm 0.6$ & $6.4 \pm 0.4$ & $7.2 \pm 1.1$ & $5.9 \pm 0.3$ & $5.5 \pm 0.2$ \\
\hline
\end{tabular}

n: the number of samples

\section{Species richness}

The nested ANOVA shows only grazing to have a significant effect on species richness (Table 1). Between the LG and HG sites, Bethlehem had significantly higher total species richness at LG than HG sites, and so did Bloemfontein, but in Kimberley no significant difference was found between LG and HG sites (Fig. 2). In addition, we found that species richness for grasses was lower at HG than LG sites in Bethlehem, while species richness for forbs was lower at HG than LG sites in Bloemfontein.
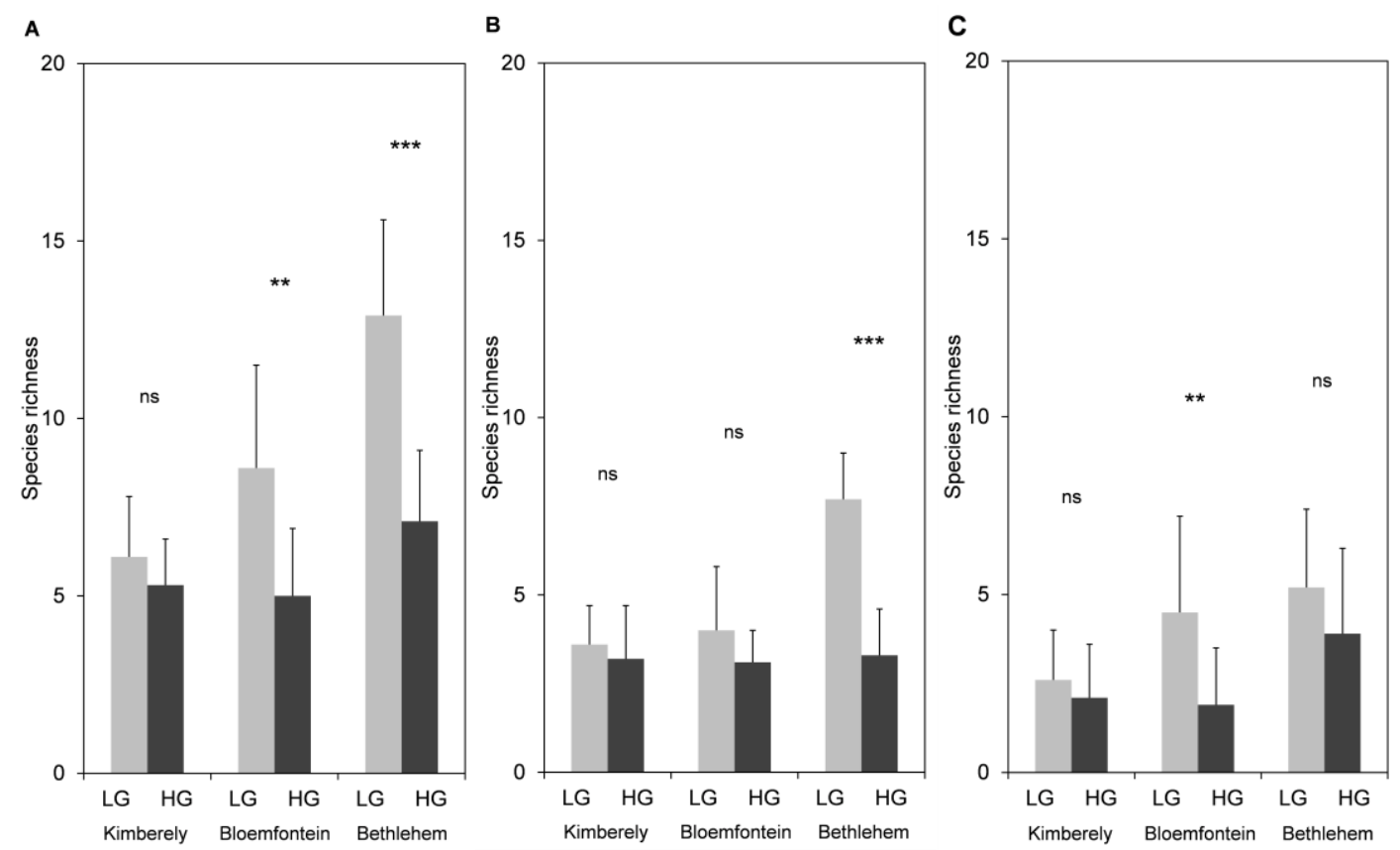

Figure 2. Total (A), grass $(B)$ and forb $(C)$ species richness at low and high grazing sites ( $L G$ and $H G$, respectively) in semi-arid grasslands of South Africa. The grey and black bars indicate $L G$ and $H G$, respectively. The values are means and standard deviations. $n$ is the number of samples. 


\section{Relationship between biomass and species richness}

When we regressed species richness with biomass, we found a quadratic (humpshaped) relationship ( $r=0.500, \mathrm{n}=41, p=0.004$; Fig. 3), although there was also a weaker positively linear relationship $(r=0.366, \mathrm{n}=41, p=0.019)$. This pattern was sensitive to grazing intensity, and this was evident when we differentiated between LG and HG sites. We found positively linear relationships at both LG and HG sites across the study area ( $r=0.493, \mathrm{n}=28, p=0.008$ for LG sites; $r=0.554, \mathrm{n}=13, p=0.049$ for HG sites; Fig. 3). The slope of the fitted line was 0.01 for LG and 0.003 for HG; a onetailed $t$-test was used to examine if there was a significant difference in slope and it confirms the alternative hypothesis $(\mathrm{t}=-1.879, \mathrm{df}=37, p=0.034)$.

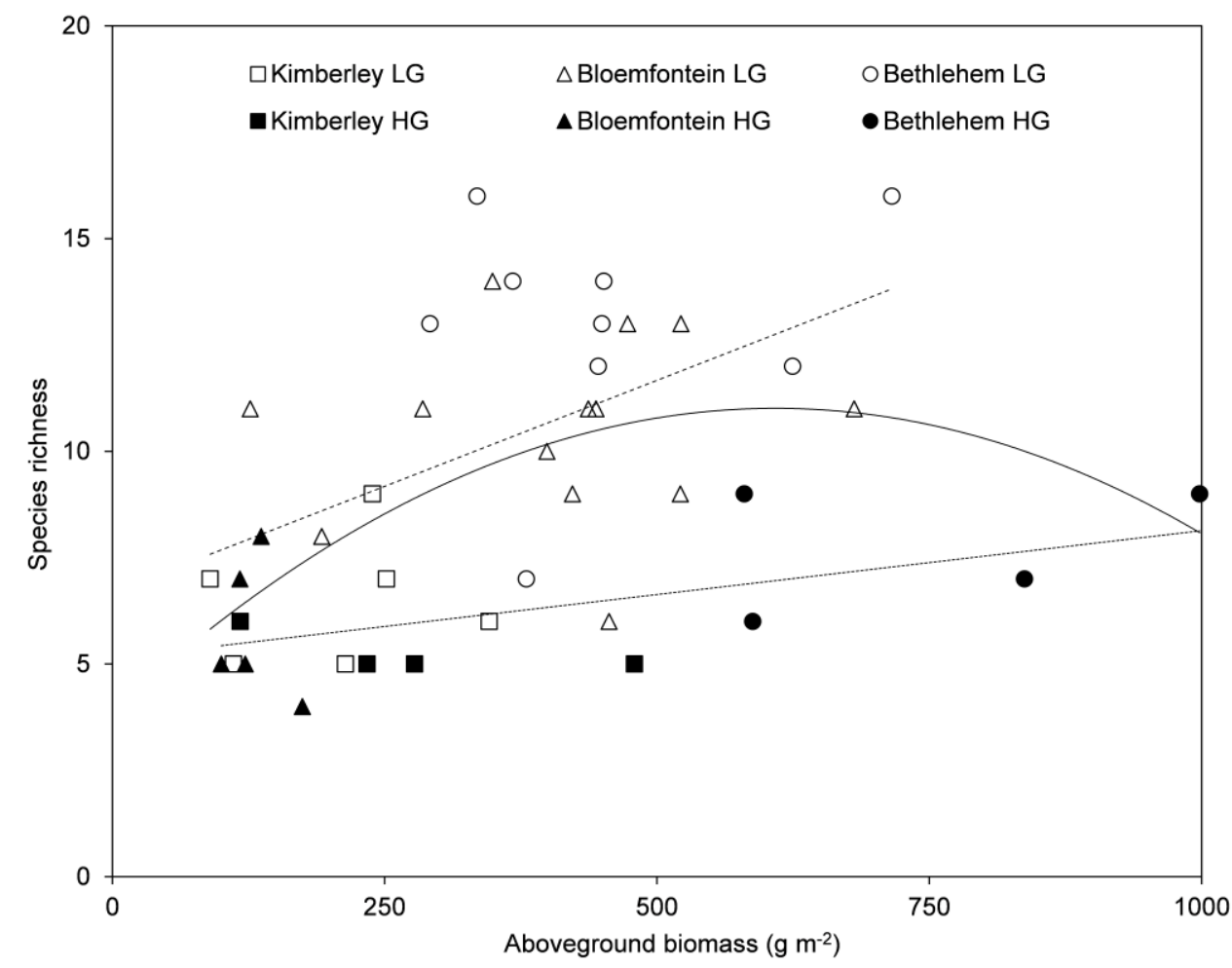

Figure 3. Relationship between species richness and aboveground biomass at regional scale (Bethlehem, Bloemfontein and Kimberly) in semi-arid grassland of South Africa. The white and black dots represent sites under low grazing $(L G)$ and high grazing $(H G)$, respectively. The solid hump-shaped curve indicates the relationship between species richness and aboveground biomass with all sites included, without differentiating between grazing intensities; the dashed and dotted lines show the relationship with $L G$ and $H G$ sites, respectively.

\section{Discussion}

\section{Soil properties, biomass and species richness along the rainfall gradient}

Soil properties are important determinants of biomass production, species richness and species composition (Berendse et al., 1998; Janssens et al., 1998; Laughlin and Abella, 2007). In particular, plant growth and biomass production largely depend on the supply of soil $\mathrm{N}$. Although soil $\mathrm{N}$ can be an explanatory factor of biomass production across locations when soil water availability is not different between the locations, the relationships of biomass with soil properties are however not simple for wide 
environmental gradients (Schaffers, 2002a). This is evident in our study, where the rainfall gradient of the study area was relatively large, ranging between $467 \mathrm{~mm}$ and $716 \mathrm{~mm}$. As in other semi-arid grasslands, soil water availability is the most limiting factor to plant growth in our study area. Variation in annual net primary productivity of semi-arid grasslands is by and large associated with variation in summer (plant growing season) rainfall (Knapp et al., 2006) as well as annual rainfall (O'Connor et al., 2001).

In our study area, the spatial variation in rainfall is characterised by an increasing trend from west to east. Accordingly, there is an increasing trend of aboveground biomass with increasing rainfall. The positive geographical gradient is also detected with $\mathrm{N}$ accumulated in the soil, which can partly be linked to the effect of biomass production. This is mainly because more biomass is produced in the relatively high rainfall area of Bethlehem than the low rainfall areas (Bloemfontein and Kimberley), resulting in more decomposable organic matter and subsequently more soil $\mathrm{N}$ in Bethlehem. In addition, species richness positively influences soil $\mathrm{N}$ accumulation (Fornara and Tilman, 2008) and thus, the higher $\mathrm{N}$ in Bethlehem can be partially ascribed to high species richness and vice versa for Bloemfontein and Kimberley. On the contrary, the higher accumulation of soil organic matter results in lower soil $\mathrm{pH}$ (Berendse et al., 1998) and this explains why we observed a negative geographical gradient for soil $\mathrm{pH}$, decreasing with the increasing rainfall from Kimberley to Bethlehem. According to FAO/IIASA/ISRIC/ISSCAS/JRC (2009), the soils of the Free State Province are generally acidic in the east (relatively high rainfall) and alkaline in the west (relatively low rainfall). The main driver responsible for less acidic soils in semi-arid grassland is the lower intensity in leaching of the soil in drier areas than in high precipitation areas (Troeh and Thompson, 1993).

\section{Grazing and soil chemical properties}

Our results showed that the macronutrients $(\mathrm{N}, \mathrm{P}$ and $\mathrm{K})$ were not different between $\mathrm{LG}$ and $\mathrm{HG}$ sites, but two cations $(\mathrm{Ca}$ and $\mathrm{Mg}$ ) were shown to be different and hence $\mathrm{pH}$ (Table 1). We can use our two grazing categories (LG and $\mathrm{HG}$ ) and the soil $\mathrm{pH}$ classification of USDA Soil Survey Division Staff (1993) to classify the grasslands surveyed in our three study locations as follows: both LG and HG sites in Bethlehem are regarded as moderately acidic grasslands, LG and HG sites in Bloemfontein as slightly acidic and neutral grasslands, respectively, and LG and HG sites in Kimberley as neutral and slightly alkaline grasslands, respectively. The classification of the LG and HG sites into acidic and alkaline grasslands is by no means an inference on the role of grazing on the acidity/alkalinity of the soils of our study area. This is largely because there is no consistency in the findings of studies on the impact of grazing on soil $\mathrm{pH}$, for example, Cui et al. (2005), Jeddi and Chaieb (2010), Steffens et al. (2008), Tefera et al. (2010) and Xie and Wittig (2004).

The present study has also highlighted this inconsistency between our three study locations. In the moderately acidic grasslands (Bethlehem), higher soil acidity is likely to occur with HG than LG sites (Table 2). In other similar acidic soils, studies often report no impact of grazing on soil $\mathrm{pH}$ e.g. semi-arid savannas of Swaziland (Tefera et al., 2010). In Bloemfontein, relatively high soil $\mathrm{pH}$ occurs under high grazing, compared with low grazing (Table 2). In the Inner Mongolia region of China, a similar result was found by Cui et al. (2005), who reported that soil $\mathrm{pH}$ decreased with a longterm (30 years) exclusion of livestock grazing, but on the contrary Steffens et al. (2008) reported that soil $\mathrm{pH}$ increased with seasonal grazing or an exclusion of livestock 
grazing, compared with continuous grazing. As to alkaline grasslands, Jeddi and Chaieb (2010) reported that a long-term (12 years) exclusion of livestock grazing increased species richness and decreased soil $\mathrm{pH}$ from moderate alkalinity to slight alkalinity in degraded arid steppe of Tunisia. The present study showed no difference in soil $\mathrm{pH}$ between LG and HG sites in the relatively alkaline soils in Kimberley (Table 2). This is further supported by Xie and Wittig (2004), who reported no change in $\mathrm{pH}$ of a moderately alkaline soil with a long-term (18 years) exclusion of livestock grazing in the Ningxia Hui region of China. These inconsistencies among studies may be due to differences in grazing management conditions and climatic zones.

\section{Patterns of species richness and composition with grazing}

The impact of grazing intensity on species richness does not follow a single general pattern either. In semi-arid environment, the relationship is known to be negatively linear (Milchunas and Lauenroth, 1993), but the hump-shaped relationship, which is generally observed in sub-humid environment (Taddese et al., 2002), may exist under semi-arid conditions (Oba et al., 2001). According to Olff and Ritchie (1998), the relationship rather depends on the environmental gradient of soil fertility and precipitation. In concurrence, we found no significant difference in species richness between LG and HG sites in Kimberley. In this region, rainfall is low and so is soil fertility observed through the main indicator $\mathrm{N}$; biomass production is consequently low and so is species richness. Thus precipitation and soil ferility have an overriding effect on species richness, and not grazing.

With regard to species composition, Oba et al. (2001) reported that the species richness of grasses (and also shrubs) in an Acacia-bushed grassland of Kenya was higher in seasonally grazed land (dry-season grazing and wet-season non-grazing) than year-round grazed land, while there was no difference in forb species richness between the grazing practices. Similarly, comparisons between HG and LG sites in our study showed a lower number of grasses in HG sites and no difference in forb richness with high grazing in Bethlehem (Fig. 2). In Bloemfontein, however, no difference in grass species richness was detected but the significantly lower number of forb species in HG sites mostly contributed to the discrepancy in total species richness between HG and LG sites. On the contrary, Rutherford and Powrie (2011) reported a significant increase in the number of forb species with heavy grazing of communal land in the Eastern Cape Province of South Africa. Regardless of these inconsistencies, total species richness can be modified by grazing. This indicates that grasslands under semi-arid conditions need to be well maintained at a moderate level of grazing intensity, as suggested by several previous studies in other grasslands.

\section{Biodiversity-productivity relationship in semi-arid grassland}

The relationship between species richness and biomass is complex and shows no single general pattern (e.g. Bai et al., 2007; Mittelbach et al., 2001; Gillman and Wright, 2006; Tilman et al., 2001). Adler et al. (2011) revealed the relationship to be humpshaped (although weak) at global scale, while the meta-analysis of Mittelbach et al. (2001) shows that hump-shaped relationships are mostly seen at local to landscape scales. The observations of Mittelbach et al. (2001) are consistent with our findings, as well as those of Oba et al. (2001), who also reported a similar hump-shaped model at local scale. What makes the relationship complex are the confounding effects of 
environmental stress conditions and disturbance. Several studies, including Michalet et al. (2006) have shown biomass to explain only a limited proportion of the variation in species richness, indicating that environmental factors are also important. Furthermore, Schaffers (2002b) reported a hump-shaped relationship but suggested that such a relationship may arise from the covariation of biomass with other factors, especially soil $\mathrm{pH}$, moisture content, the available $\mathrm{N}: \mathrm{P}$ ratio and management (mowing). Gough et al. (1994) found elevation, salinity and organic matter to be better predictors of species richness than biomass alone. Similarly, in our study we examined the effect of soil properties and livestock grazing on the relationship and found soil $\mathrm{N}, \mathrm{pH}$ and grazing to be important explanatory variables. We can interprete the hump-shaped relationship in relation to soil characteristics, especially $\mathrm{pH}$ as follows: species richness increases with increasing biomass in association with decreasing $\mathrm{pH}$ from the slightly alkaline/neutral soil to the slightly acidic soil (Kimberley and Bloemfontein) and subsequently declines with increasing biomass associated with decreasing $\mathrm{pH}$ in the moderately acidic soils (Bethlehem).

\section{Effect of grazing on the biodiversity-productivity relationship}

The relationship between species richness and biomass is sensitive to grazing because the hump-shaped model revealed in our study becomes positively linear when LG and HG sites are differentiated (Fig. 3). This is supported by findings in other similar studies. For example, Adler et al. (2011) showed the global hump-shaped model to be sensitive to land-use history (i.e. becomes positively linear under fire management and grazing). Likewise, the hump-shaped model reported by Oba et al. (2001) for arid grazing land becomes positively linear in year-round high grazing. In our study, the hump-shaped relationship could result from low species richness with low biomass at both LG and HG sites in Kimberley, an increase in species richness from HG to LG with increasing biomass in Bloemfontein, and a decline in species richness from LG to HG with increasing biomass in Bethlehem (Fig. 3). It is worth noting that the perceived discrepancy of higher biomass in HG than LG sites in Bethlehem could be due to selective grazing. The majority of HG plots were dominated by the unpalatable grasses, i.e. Cymbopogon plurinodis and Elionurus muticus (Brockett, 1983; Snyman, 2007). These species potentially grow larger than the other species observed at the sites.

\section{Conclusion}

The findings of our study have revealed the biodiversity-productivity relationship to be hump-shaped across the study area, but it is sensitive to grazing and its potential effects on soil $\mathrm{pH}$. The relationship therefore has to be carefully interpreted in grazing land. Although a number of studies have shown the overriding effect of rainfall variability on vegetation change, rather than grazing variables in arid and semi-arid environments (Cheng et al., 2011; Milchunas and Lauenroth, 1993; Sullivan and Rohde, 2002), we did not detect this effect because the climatic conditions were relatively wet in both the two years when we conducted this study. A further examination needs to be undertaken to understand the inter-annual variability of the relationship, especially in relation to seasonal rainfall. 
Acknowledgements. We thank the National Research Foundation of South Africa and the Strategic Cluster: Water Management in Water-Scarce Areas (University of the Free State) for the financial assistance, as well as the following people from the University of the Free State: Ms. Y. Dessels and the Soil Science Laboratory staff for the soil analysis; and Prof. P.J. du Preez for assisting with species identification.

\section{REFERENCES}

[1] Adler, P.B., Levine, J.M. (2007): Contrasting relationships between precipitation and species richness in space and time. - Oikos 116: 221-232.

[2] Adler, P.B., Seabloom, E.W., Borer, E.T., Hillebrand, H., Hautier, Y., Hector, A., Harpole, W.S., O’Halloran, L.R., Grace, J.B., Anderson, T.M., Bakker, J.D., Biederman, L.A., Brown, C.S., Buckley, Y.M., Calabrese, L.B., Chu, C.J., Cleland, E.E., Collins, S.L., Cottingham, K.L., Crawley, M.J., Damschen, E.I., Davies, K.F., DeCrappeo, N.M., Fay, P.A., Firn, J., Frater, P., Gasarch, E.I., Gruner, D.S., Hagenah, N., Lambers, J.H.R., Humphries, H., Jin, V.L., Kay, A.D., Kirkman, K.P., Klein, J.A., Knops, J.M.H., La Pierre, K.J., Lambrinos, J.G., Li, W., MacDougall, A.S., McCulley, R.L., Melbourne, B.A., Mitchell, C.E., Moore, J.L., Morgan, J.W., Mortensen, B., Orrock, J.L., Prober, S.M., Pyke, D.A., Risch, A.C., Schuetz, M., Smith, M.D., Stevens, C.J., Sullivan, L.L., Wang, G., Wragg, P.D., Wright, J.P., Yang, L.H. (2011): Productivity is a poor predictor of plant species richness. - Science 333: 1750-1753.

[3] Anderson, R.H., Fuhlendorf, S.D., Engl,e D.M. (2006): Soil nitrogen availability in tallgrass prairie under the fire-grazing interaction. - Rangeland Ecology and Management 59: 625-631.

[4] Anderson, T.M., Ritchie, M.E., McNaughton, S.J. (2007). Rainfall and soils modify plant community response to grazing in Serengeti National Park. - Ecology 88: 1191-1201.

[5] Bai, Y., Wu, J., Pan, Q., Huang, J., Wang, Q., Li, F., Buyantuyev, A., Han, X. (2007): Positive linear relationship between productivity and diversity: evidence from the Eurasian Steppe. - Journal of Applied Ecology 44: 1023-1034.

[6] Berendse, F., Lammerts, E.J., Olff, H. (1998): Soil organic matter accumulation and its implications for nitrogen mineralization and plant species composition during succession in coastal dune slacks. - Plant Ecology 137: 71-78.

[7] Brockett, GM. (1983): The effect of defoliation on the persistence of Elionurus muticus (Spreng.) Kunth in the highland sourveld of Nata. - African Journal of Range and Forage Science 18: 81-83.

[8] Cheng, Y., Tsubo, M., Ito, T.Y., Nishihara, E., Shinoda, M. (2011): Impact of rainfall variability and grazing pressure on plant diversity in Mongolian grasslands. - Journal of Arid Environments 75: 471-476.

[9] Critchley, C.N.R., Chambers, B.J., Fowbert, J.A., Sanderson, R.A., Bhogal, A., Rose, S.C. (2002): Association between lowland grassland plant communities and soil properties. - Biological Conservation 105: 199-215.

[10] Cui, X., Wang, Y., Niu, H., Wu, J., Wang, S., Schnug, E., Rogasik, J., Fleckenstein, J., Tang, Y. (2005): Effect of long-term grazing on soil organic carbon content in semiarid steppes in Inner Mongolia. - Ecological Research 20: 519-527.

[11] FAO/IIASA/ISRIC/ISSCAS/JRC. (2009): Harmonized World Soil Database (version 1.1). - FAO and Luxenburg: IIASA, Rome.

[12] Fernandez-Gimenez, M., Allen-Diaz, B. (2001): Vegetation change along gradients from water sources in three grazed Mongolian ecosystems. - Plant Ecology 157: 101-118.

[13] Fornara, D.A., Tilman, D. (2008): Plant functional composition influences rates of soil carbon and nitrogen accumulation. - Journal of Ecology 96: 314-322.

[14] Fox, J.W. (2013): The intermediate disturbance hypothesis should be abandoned. - Trends in Ecology and Evolution 28: 86-92. 
[15] Gillman, L.N., Wright, S.D. (2006): The influence of productivity on the species richness of plants: a critical assessment. - Ecology 87: 1234-1243.

[16] Gough, L., Grace, J.B., Taylor, K.L. (1994): The relationship between species richness and community biomass: the importance of environmental variables. - Oikos 70: 271279.

[17] Hector, A., Schmid, B., Beierkuhnlein, C., Caldeira, M.C., Diemer, M., Dimitrakopoulos, P.G., Finn, J.A., Freitas, H., Giller, P.S., Good, J., Harris, R., Högberg, P., Huss-Danell, K., Joshi, J., Jumpponen, A., Körner, C., Leadley, P.W., Loreau, M., Minns, A., Mulder, C.P.H., O’Donovan, G., Otway, S.J., Pereira, J.S., Prinz, A., Read, D.J., SchererLorenzen, M., Schulze, E.D., Siamantziouras, A.S.D., Spehn, E.M., Terry, A.C., Troumbis, A.Y., Woodward, F.I., Yachi, S., Lawton, J.H. (1999): Plant diversity and productivity experiments in European grasslands. - Science 286: 1123-1127.

[18] Hejcman, M., Češková, M., Schellberg, J., Pätzold, S. (2010): The Rengen Grassland Experiment: effect of soil chemical properties on biomass production, plant species composition and species richness. - Folia Geobotanica 45: 125-142.

[19] Huston, M.A., Aarssen, L.W., Austin, M.P., Cade, B.S., Fridley, J.D., Garnier, E., Grime, J.P., Hodgson, J., Lauenroth, W.K., Thompson, K., Vandermeer, J.H., Wardle, D.A. (2000): No consistent effect of plant diversity on productivity. - Science 289: 1255a.

[20] Janssens, F., Peeters, A., Tallowin, J.R.B., Bakker, J.P., Bekker, R.M., Fillat, F., Oomes, M.J.M. (1998): Relationship between soil chemical factors and grassland diversity. Plant and Soil 202: 69-78.

[21] Jeddi, K., Chaieb, M. (2010): Changes in soil properties and vegetation following livesock grazing exclusion in degraded arid environments of South Tunisia. - Flora 205: 184-189.

[22] Knapp, A.K., Burns, C.E., Fynn, R.W.S., Kirkman, K.P., Morris, C.D., Smith, M.D. (2006): Convergence and contingency in production-precipitation relationships in North American and South African C4 grasslands. - Oecologia 149: 456-464.

[23] Laughlin, D.C., Abella, S.R.. (2007): Abiotic and biotic factors explain independent gradients of plant community composition in ponderosa pine forests. - Ecological Modelling 205: 231-240.

[24] Michalet, R., Brooker, R.W., Cavieres, L.A., Kikvidze, Z., Lortie, C.J., Pugnaire, F.I., Valiente-Banuet, A., Callaway, R.M. (2006): Do biotic interactions shape both sides of the humped-back model of species richness in plant communities? - Ecology Letters 9: $767-773$.

[25] Middleton, N., Thomas, D.S.G. (1992): World Atlas of Desertification. - UNDP/Edward Arnold, London.

[26] Milchunas, D.G., Lauenroth, W.K. (1993): Quantitative effects of grazing on vegetation and soils over a global range of environments. - Ecological Monographs 63: 327-366.

[27] Mittelbach, G.G., Steiner, C.F., Scheiner, S.M., Gross, K.L., Reynolds, H.L., Waide, R.B., Willig, M.R., Dodson, S.I., Gough, L. (2001): What is the observed relationship between species richness and productivity. - Ecology 82: 2381-2396.

[28] Non-Affiliated Soil Analysis Work Committee. (1990): Handbook of Standard Soil Testing Methods for Advisory Purposes. - Soil Science Society of South Africa, Pretoria.

[29] Oba, G., Vetaas, O.R., Stenseth, N.C. (2001): Relationships between biomass and plant species richness in arid-zone grazing lands. - Journal of Applied Ecology 38: 836-845.

[30] O'Connor, T.G., Haines, L.M., Snyman, H.A. (2001): Influence of precipitation and species composition on phytomass of a semi-arid African grassland. - Journal of Ecology 89: 850-860.

[31] Olff, H., Ritchie, M.E. (1998): Effects of herbivores on grassland plant diversity. - Trends in Ecology and Evolution 13: 261-265.

[32] Roem, W.J., Berendse, F. (2000): Soil acidity and nutrient supply ratio as possible factors determining changes in plant species diversity in grassland and heathland communities. Biological Conservation 92: 151-161. 
[33] Rutherford, M.C., Powrie, L.W. (2011): Can heavy grazing on communal land elevate plant species richness levels in the Grassland Biome of South Africa? - Plant Ecology 212: $1407-1418$.

[34] Snyman, H.A. (2007): Short-term influence of fire in a semi-arid grassland on (8): two less palatable grass species (Cymbopogon plurinodis and Elionurus muticus). - Grassroots 7: $11-23$.

[35] Schaffers, A.P. (2002a): Soil, biomass, and management of semi-natural vegetation. Part I: Interrelationships. - Plant Ecology 158: 229-246.

[36] Schaffers, A.P. (2002b): Soil, biomass, and management of semi-natural vegetation. Part II: Factors controlling species diversity. - Plant Ecology 158: 247-268.

[37] Snyman, H.A. (1998). Dynamics and sustainable utilization of rangeland ecosystems in arid and semi-arid climates of southern Africa. - Journal of Arid Environment 39: 645666.

[38] Steffens, M., Kölbl, A., Totsche, K.U., Kögel-Knabner, I. (2008): Grazing effects on soil chemical and physical properties in a semiarid steppe of Inner Mongolia (P.R. China). Geoderma 143: 63-72.

[39] Stohlgren, T.J., Schell, L.D., Van den Heuvel, B. (1999): How grazing and soil quality affect native and exotic plant diversity in rocky mountain grasslands. - Ecological Applications 9: 45-64.

[40] Sullivan, S., Rohde, R. (2002): On non-equilibrium in arid and semi-arid grazing systems. - Journal of Biogeography 29: 1595-1618.

[41] Taddese, G., Mohamed Saleem, M.A., Abyie, A., Wagnew, A. (2002): Impact of grazing on plant species richness, plant biomass, plant attribute, and soil physical and hydrological properties of vertisol in East African highlands. - Environmental Management 29: 279-289.

[42] Tainton, N. (1999): Veld Management in South Africa. - University of Natal Press, Pietermaritzburg.

[43] Tefera, S., Dlamini, B.J., Dlamini, A.M. (2010): Changes in soil characteristics and grass layer condition in relation to land management systems in the semi-arid savannas of Swaziland. - Journal of Arid Environments 74: 675-684.

[44] Tilman, D. (1999): The ecological consequences of changes in biodiversity: a search for general principles. - Ecology 80: 1455-1474.

[45] Tilman, D., Reich, P.B., Knops, J., Wedin, D., Mielke, T., Lehman, C. (2001): Diversity and productivity in a long-term grassland experiment. - Science 294: 843-845.

[46] Troeh, F.R., Thompson, LM. (1993): Soils and soil fertility (5th edn). Oxford University Press, New York.

[47] USDA Soil Survey Division Staff. (1993): Soil Survey Manual. - Soil Conservation Service, U.S. Department of Agriculture (USDA) Handbook 18.

[48] Van Oudtshoorn, F. (1999): Guide to Grasses of Southern Africa. - Briza, Pretoria.

[49] Waide, R.B., Willig, M.R., Steiner, C.F., Mittelbach, G., Gough, L., Dodson, S.I., Juday, G.P., Parmenter, R. (1999): The relationship between productivity and species richness. Annual Review of Ecology and Systematics 30: 257-300.

[50] Willig, M.R. (2011): Biodiversity and productivity. - Science 333: 1709-1710.

[51] Yates, C.J., Norton, D.A., Hobbs, R.J. (2000): Grazing effects on plant cover, soil and microclimate in fragmented woodlands in south-western Australia: implications for restoration. - Austral Ecology 25: 36-47.

[52] Xie, Y., Wittig, R. (2004): The impact of grazing intensity on soil characteristics of Stipa grandis and Stipa bungeana steppe in northern China (autonomous region of Ningxia). Acta Oecologica 25: 197-204. 